\title{
ANALISIS KEMAMPUAN BERPIKIR KRITIS SISWA PADA MATERI POKOK SISTEM PENCERNAAN MANUSIA DI KELAS XI IPA SMA SWASTA YAPIM BIRU-BIRU
}

\author{
Sri Dewi Nainggolan ${ }^{1 *}$, Cicik Suriani ${ }^{2}$, Elista Sianturi ${ }^{3}$ \\ ${ }^{12}$ Program Studi Pendidikan Biologi, FMIPA, Universitas Negeri Medan, Jl. Willem Iskandar Psr. V, Medan \\ Estate, Medan, Indonesia, 20221 \\ ${ }^{3}$ Guru Biologi SMA Swasta YAPIM Biru-biru, Jl. Besar Delitua, Kec.Sibiru-biru, Kab.Deli Serdang, Indonesia 20355 \\ *E-mail : sridewinainggolan35@gmail.com
}

\begin{abstract}
ABSTRAK
Penelitian ini bertujuan untuk mengetahui bagaimana kemampuan berpikir kritis siswa pada materi pokok sistem pencernaan manusia di kelas XI IPA SMA Swasta YAPIM Biru-biru, Delitua Tahun Pembelajaran 2017/2018. Populasi penelitian ini adalah seluruh siswa kelas XI IPA YAPIM Biru-biru, Delitua yang terdiri atas tiga kelas berjumlah 98 siswa. Sampel penelitian terdiri atas satu kelas yaitu XIIPA 3 sebanyak 34 siswa dan pengambilan sampel dilakukan dengan teknik random sampling. Jenis penelitian adalah penelitian deskriptif kuantitatif. Instrumen penelitian yang digunakan adalah tes kemampuan berpikir kritis sebanyak 25 soal dan lembar observasi. Hasil penelitian menunjukkan bahwa kemampuan berpikir kritis siswa pada materi Sistem Pencernaan Manusia di kelas XI IPA SMA Swasta YAPIM Biru-biru, Delitua Tahun Pembelajaran 2017/2018 berada padakriteria cukup sampai dengan sangat baik $(79,41 \%)$ sebanyak 27 siswa. Rata-rata kemampuan berpikir kritis paling tinggi ditemukan pada indikator 4 (Mengobservasi dan mempertimbangkan hasil observasi)yaitu sebesar $81 \%$, sedangkan rata-rata kemampuan berpikir kritis paling rendah ditemukan pada indikator 2 (Bertanya dan menjawab pertanyaan) yaitu sebesar 59,65\%.
\end{abstract}

Kata Kunci : Kemampuan Berpikir Kritis, Materi Pokok Sistem Pencernaan Manusia

\section{ABSTRACT}

This study aims to determine how students' critical thinking ability on the subject matter of human digestive system in class XI IPA SMA SWASTA YAPIM Biru-biru, Delitua Year Learning 2017/2018. The population of this study is all students of class XI IPA YAPIM Biru-biru, Delitua consisting of three classes amounted to 98 students. The sample of research consist of one class that is XI IPA 3 as many as 34 students and sampling is done by random sampling technique. The research type is quantitative descriptive research. The research instrument used is the knowledge test of 25 questions and the observation sheet. The result of the research shows that students' critical thinking ability in the human digestion system in class XI IPA SMA Swasta YAPIM Biru-biru, Delitua learning year $2017 / 2018$ is on the criteria quite up to very good $(79,41 \%)$ as many as 27 students. The highest average of critical thinking ability is found in indicator 4 (Observing and considering the observation result) is $81 \%$, meanwhile the lowest critical thinking ability is found in indicator 2 (Question and answer) is $59.65 \%$.

Keywords: Critical Thinking Ability, Basic Material of Human Digestive System

\section{PENDAHULUAN}

Pendidikan merupakan suatu bekal yang paling berharga dalam kehidupan, karena pendidikan merupakan kunci utama dalam meraih sebuah kesuksesan. Pendidikan wajib ditanamkan pada manusia, baik di lingkungan keluarga, masyarakat, maupun sekolah. Pendidikan sekolah mengubah siswa agar dapat memiliki pengetahuan, keterampilan dan sikap belajar serta perubahan perilaku belajar sehingga tujuan pendidikan tercapai (Erdi, 2014).

Proses pembelajaran yang dikembangkan di Indonesia sangat menuntut siswa untuk terlibat secara aktif dalam proses kegiatan belajar mengajar sehingga kemampuan pemecahan masalahnya menjadi lebih berkembang. Terkait dengan aspek kemampuan pemecahan masalah dalam pembelajaran dituntut siswa untuk memiliki suatu kemampuan berpikir yang lebih tinggi, hal ini dikarenakan berpikir merupakan suatu aktivitas mental yang dilakukan seseorang untuk membantu merumuskan atau memecahkan masalah dan membuat keputusan yang tepat sesuai dengan yang dinginkannya (Harjanto, 2011). Pada hakikatnya pembelajaran biologi berkaitan dengan cara mencari tahu dan memahami tentang alam secara 
sistematis sehingga pembelajaran biologi bukan hanya penguasaan kumpulan pengetahuan yang berupa konsep-konsep, fakta-fakta, tetapi juga merupakan suatu proses penemuan, sehingga siswa dituntut untuk dapat berpikir kritis. Oleh karena itu, pengembangan keterampilan berpikir kritis menjadi sangat penting bagi siswa di setiap jenjang pendidikan (Arnyana, 2006).

Berpikir kritis merupakan sebuah proses yang terarah dan jelas yang digunakan dalam kegiatan mental seperti memecahkan masalah, mengambil keputusan, membujuk, menganalisis asumsi, dan melakukan penelitian ilmiah. Baron dan Stemberg (1987) menyatakan bahwa berpikir kritis merupakan suatu pikiran yang difokuskan untuk memutuskan apa yang diyakini untuk dilakukan. Definisi ini merupakan gabungan dari lima hal dasar dalam berpikir kritis yaitu praktis, reflektif, masuk akal, keyakinan dan tindakan. Pendapat serupa juga diungkapkan Ennis (1991) yang mendefinisikan bahwa berpikir kritis merupakan suatu proses penggunaan kemampuan berpikir secara rasional dan reflektif yang bertujuan untuk mengambil keputusan tentang apa yang diyakini atau dilakukan (Nurhidayati, 2011). Kemampuan berpikir kritis seorang siswa menentukan bagaimana siswa tersebut berpikir secara rasional, berargumentasi, mengklasifikasi, menafsirkan, sehingga kemampuan berpikir kritis akan menjadikan seseorang siswa mampu belajar dan berkomunikasi di dalam diskusi lebih mudah (Ardhi. W., 2012).

Hasil belajar merupakan kemampuankemampuan yang dimiliki siswa setelah menerima pengalaman belajarnya. Menurut Djamarah (2010) istilah hasil belajar berasal dari bahasa Belanda "prestatie", dalam bahasa Indonesia menjadi prestasi yang berarti hasil usaha. Prestasi selalu dihubungkan dengan aktivitas tertentu, seperti dikemukakan oleh Gagne dalam Suprihatiningrum (2013) bahwa dalam setiap proses akan selalu terdapat hasil nyata yang dapat diukur dan dinyatakan sebagai hasil belajar (achievement) seseorang. Gagne membagi lima kategori hasil belajar, yakni (a) informasi verbal, (b) keterampilan intelektual, (c) strategi kognitif, (d) sikap, (e) keterampilan motoris (Sudjana, N, 2008).

Penelitian tentang analisis kemampuan berpikir kritis siswa pernah dilakukan oleh Yunita, (2016) melakukan penelitian tentang analisis kemampuan berpikir kritis dan hasil belajar siswa pada pembelajaran biologi di kelas X Madrasah Aliyah Negeri 1 Medan tahun pembelajaran 2015/2016 melaporkan berdasarkan rentang dengan sebaran data terbesar berada pada rentang 16-22 dengan banyak siswa (frekuensi) sebanyak 21 siswa dengan persentase sebesar 52,2\% dari 40 siswa sedangkan sebaran data terkecil berada pada rentang 30-36 dengan banyak siswa (frekuensi) sebanyak 1 siswa dengan persentase sebesar 2,5\% dari 40 siswa. Dari penelitian di atas dapat disimpulkan bahwa kemampuan berpikir kritis siswa kelas X IPA MAN 1 Medan tahun pembelajaran 2015/2016 pada kategori cenderung cukup.

Berdasarkan hasil observasi peneliti di SMA YAPIM Biru-biru, Delitua pada bulan September di kelas XI IPA, peneliti menemukan beberapa masalah dalam pembelajaran biologi yaitu kemampuan berpikir kritis siswa dalam mengikuti pembelajaran masih belum terlihat. Hal ini dapat diketahui ketika proses pembelajaranberlangsung, siswa hanya berpusat pada guru (konvensional), dimana peran guru lebih dominan sehinga siswa cenderung pasif, respon siswa terlihat rendah. Kegiatan dalam pembelajaran konvensional diawali dengan guru menjelaskan konsep secara informatif, memberikan contoh soal dan diakhiri dengan pemberian latihan soal-soal. Akibatnya siswa lebih diarahkan pada proses menghafal dari pada memahami konsep sehingga kemampuan berpikir siswa menjadi kurang berkembang (Erdi, S., 2014).

Hasil wawancara dengan guru bidang studi mata pelajaranBiologi SMA YAPIMBiru-biru, Delitua, Elista Sianturi, S.Pd, diketahui masih banyak siswa yang kurang menggunakan kemampuan berpikir kritis ditandai dengan masih adanya data nilai siswa, dimana $64.7 \%$ (22 orang dari 34 siswa) masih dibawah nilai KKM (80) ketika belajar materi Sistem Pencernaan Manusia.

Tentunya permasalahan tersebut mengakibatkan rendahnya proses berpikir siswa. Berdasarkan latar belakang yang telah dipaparkan, maka peneliti perlu mengkaji Analisis Kemampuan Berpikir Kritis Siswa pada Materi Pokok Sistem Pencernaan Manusia di Kelas XI IPA SMA Swasta YAPIM Biru-biru,Delitua Tahun Pembelajaran $2017 / 2018$.

\section{METODE PENELITIAN}

Pengumpulan data maupun informasi yang dibutuhkan dalam penelitian ini dilaksanakan di SMA Swasta YAPIM Biru-biru, yang beralamat Jl. Besar Delitua, Kec.Sibiru-biru, Kab.Deli Serdang. Penelitian dilakukan pada bulan Februari sampai dengan April 2018.

Populasi pada penelitian ini seluruh siswa kelas XI IPA yang berjumlah 98 orang. Sampel yang digunakan dalam penelitian adalah kelas XI IPA dengan teknik Random Sampling. 
Instrumen penelitian ini yaitu tes dan lembar observasi. Jenis penelitian ini adalah penelitian deskriptif berdasarkan pendekatan kuantitatif. Tujuan utama dari penelitian deskriptif adalah untuk mendeskripsikan data secara sistematik dan faktual sehingga dapat menggambarkan keadaan subjek pada saat itu atau menggambarkan keadaan lapangan (Sukardi, 2013).

Teknik analisis data yang dilakukan teknik tes kemampuan berpikir kritis digunakn untuk mengoreksi hasil pekerjaan siswa dan membuat rekapitulasi nilai hasil tes kemampuan berpikir kritis siswa dan Hasil data observasi ini digunakan untuk dapat melengkapi data-data penelitian yang telah diolah.

\section{HASIL PENELITIAN}

\section{Hasil Validitas Tes}

Dari hasil validitas tes yang valid terdapat 25 soal. Terdapat 5 soal yang memiliki daya pembeda tes kategori baik sekali, 11 soal yang memiliki daya pembeda tes kategori baik, 10 soal yang memiliki daya pembeda tes kategori cukup. Untuk tingkat kesukaran tes, ada 6 soalkategori mudah, 13 soal kategori sedang dan 6 soal kategori sukar.

\section{Hasil Penelitian}

Data kemampuan berpikir kritis siswa diperoleh dari tes berpikir kritis siswa dan lembar observasi berpikir kritis siswa di kelas. Data tersebut disajikan dalam Tabel 1 dan Tabel 2.

Tabel 1. Kemampuan Berpikir Kritis Siswa dari Hasil Tes

\begin{tabular}{ccccc}
\hline $\begin{array}{c}\text { N } \\
\text { O }\end{array}$ & $\begin{array}{c}\text { Skor } \\
\text { Kemampuan } \\
\text { Berpikir Kritis }\end{array}$ & $\begin{array}{c}\text { Frekuensi } \\
\text { Absolut }\end{array}$ & $\begin{array}{c}\text { Frekuensi } \\
\text { Relatif } \\
(\%)\end{array}$ & $\begin{array}{c}\text { Kriteria } \\
\text { Kemampuan } \\
\text { Berpikir } \\
\text { Kritis Siswa }\end{array}$ \\
\hline 1 & $91-100$ & 4 & $(11,77 \%)$ & Sangat Baik \\
2 & $76-90$ & 14 & $(41,18 \%)$ & Baik \\
3 & $56-75$ & 9 & $(26,47 \%)$ & Cukup \\
4 & $41-55$ & 6 & $(17,65 \%)$ & Kurang \\
5 & $0-40$ & 1 & $(2,94 \%)$ & Sangat \\
Kurang
\end{tabular}

Dari tabel di atas terlihat kemampuan berpikir kritis siswa berdasarkan skor kemampuan berpikir kritis dengan sebaran data tertinggi berada pada skor 76-90 dengan frekuensi absolut sebanyak 14siswa dan frekuensi relatifnya sebesar $41,18 \%$, sedangkan sebaran data terkecil berada pada skor 0-40 dengan frekuensi absolut sebanyak
1 siswa dan frekuensi relatifnya sebesar 2,94\%. Data tersebut dapat dilihat pada diagram batang kemampuan berpikir kritis siswa dari hasil tes dapat dilihat pada Gambar 1.

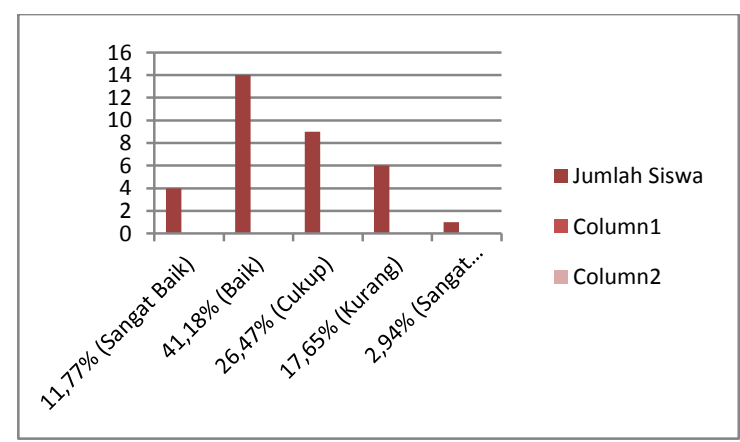

Gambar 1. Kemampuan Berpikir Kritis Siswa SMA Swasta YAPIM Biru-biru Delitua T.P 2017/2018 dari Hasil Tes

Tabel 2. Kemampuan Berpikir Kritis Siswa dari Lembar Obsevasi

\begin{tabular}{|c|c|c|c|}
\hline $\begin{array}{l}\mathbf{N} \\
\mathbf{O}\end{array}$ & $\begin{array}{c}\text { Indikator } \\
\text { Keterampilan } \\
\text { Berpikir Kritis }\end{array}$ & $\begin{array}{c}\text { Rata- } \\
\text { Rata } \\
\text { Kemamp } \\
\text { uan } \\
\text { Berpikir } \\
\text { Kritis (\%) }\end{array}$ & $\begin{array}{l}\text { Kategori } \\
\text { Indikator }\end{array}$ \\
\hline 1 & $\begin{array}{l}\text { Memfokuskan } \\
\text { Pertanyaan }\end{array}$ & $60.25 \%$ & Cukup \\
\hline 2 & $\begin{array}{l}\text { Bertanya dan } \\
\text { Menjawab } \\
\text { Pertanyaan }\end{array}$ & $59.65 \%$ & Cukup \\
\hline 3 & $\begin{array}{l}\text { Mempertimbangk } \\
\text { an Kredibilitas } \\
\text { (Kriteria) suatu } \\
\text { sumber }\end{array}$ & $80.95 \%$ & Baik \\
\hline 4 & $\begin{array}{l}\text { Mengobservasi } \\
\text { dan } \\
\text { Mempertimbangk } \\
\text { an hasil observasi }\end{array}$ & $81 \%$ & $\begin{array}{l}\text { Sangat } \\
\text { Baik }\end{array}$ \\
\hline 5 & $\begin{array}{l}\text { Mendeduksi dan } \\
\text { mempertimbangk } \\
\text { an hasil deduksi }\end{array}$ & $73.9 \%$ & Baik \\
\hline 6 & $\begin{array}{l}\text { Meninduksi dan } \\
\text { mempertimbangk } \\
\text { an hasil induksi }\end{array}$ & $72.15 \%$ & Baik \\
\hline 7. & $\begin{array}{l}\text { Memutuskan } \\
\text { suatu tindakan }\end{array}$ & $68.75 \%$ & Baik \\
\hline 8 & $\begin{array}{l}\text { Berinteraksi } \\
\text { dengan orang lain }\end{array}$ & $70.45 \%$ & Baik \\
\hline & Rata-rata & $70.88 \%$ & Baik \\
\hline
\end{tabular}


Berdasarkan Tabel 2 dari delapan indikator keterampilan berpikir kritis yang diteliti terdapat satu indikator dengan kategori sangat baik, lima indikator dengan kategori baik dan dua indikator dengan kategori cukup. Rata-rata persentase tertinggi terdapat pada indikator mengobservasi dan mempertimbangkan laporan observasi dengan nilai persentase sebesar $81 \%$. Sedangkan rata-rata persentase terendah terdapat pada indikator bertanya dan menjawab pertanyaan dengan nilai persentase sebesar $59.65 \%$. Adapun nilai rata-rata keseluruhan indikator sebesar $70.88 \%$ dengan katergori baik.Dari tabel diatas dapat dibuat diagram batang kemampuan berpikir kritis siswa dari hasil tes dapat dilihat pada Gambar 2 .

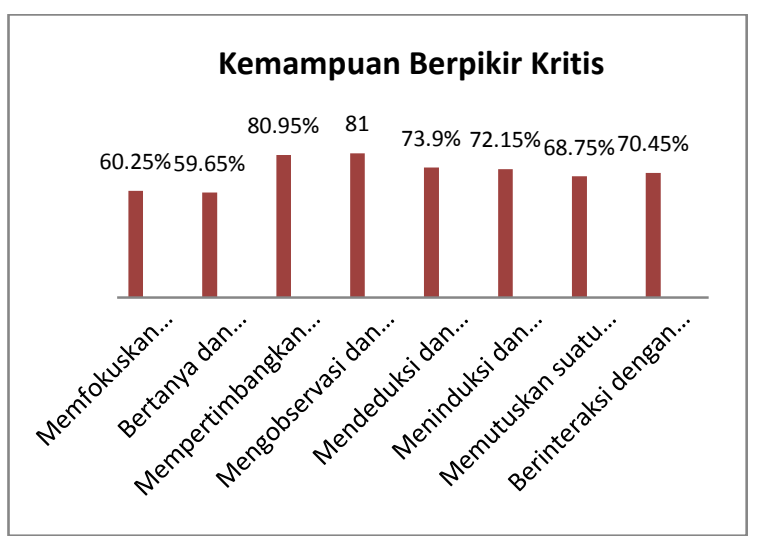

Gambar 2. Kemampuan Berpikir Kritis Siswa SMA Swasta YAPIM Biru-biru Delitua dari Hasil Observasi

\section{PEMBAHASAN}

Dari hasil analisis tes kemampuan berpikir kritis siswa, maka didapatkan 27 siswa dari 34 siswa yang mempunyai kemampuan berpikir kritis dengan kriteria cukup sampai dengan sangat baik $(79,41 \%)$, sedangkan 7 siswa yang mempunyai kemampuan berpikir kritis dengan kriteria kurang sampai dengan sangat kurang (20,59\%).

Dari hasil observasi kemampuan berpikir kritis siswa terdapat rata-rata dari keseluruhan indicator kemampuan berpikir kritis siswa yaitu 70,88\%. Indikator tertinggi terdapat pada indicator mengobservasi dan mempertimbangkan laporan hasil observasi dengan $81 \%$. Sedangkan rata-rata persentase terendah terdapat pada indicator bertanya dan menjawab pertanyaan dengan nilai $70.88 \%$. Kemampuan berpikir kritis siswa yang baik disebabkan karena pembelajaran sistem pencernaan manusia dilakukan dengan metode percobaan. Metode ini dapat menuntut siswa untuk merancang proses pencernaan manusia, melakukan percobaan, mencatat hasil percobaan, hingga membuat laporan hasil percobaan. Kegiatan tersebut memancing dan membantu siswa dalam mengembangkan kemampuan berpikir kritis.

Dalam proses pembelajaran sistem pencernaan manusia metode percobaan yang dapat melatih siswa dalam berpikir kritis karena pada prosesnya siswa benar-benar dituntun secara bertahap untuk mengarah pada berpikir kritis. Hal ini dikarenakan pada dasarnya keterampilan berpikir kritis bukanlah kemampuan yang diberikan tetapi kemampuan yang dapat dilatih dan harus dipelajari di sekolah (Arnyana, 2005).

Kemampun berpikir kritis siswa dipengaruhi oleh beberapa faktor. Faktor yang pertama adalah kondisi fisik. Siswa tidak dapat berkonsentrasi, berpikir secara cepat, dan menanggapi respon jika kondisi fisiknya terganggu atau kurang baik. Kedua adalah motivasi. Siswa tidak dapat mengikuti proses pembelajaran di kelas dengan baik jika tidak ada motivasi belajar didalam dirinya , minat, perhatian, sikap, ketekunan. Ketiga adalah kecemasan, timbul secara otomatis jika ada stimulus berlebih dan tidak dapat diterima siswa. Keempat, perkembangan intelektual, merupakan kemampuan mental seseorang dalam merespon dan menyelesaikan suatu persoalan, menghubungkan satu hal dengan yang lain, dan dapat merespon dengan baik setiap stimulus. Kelima adalah interaksi pengajar dengan siswa, suasana akademik yang bebas dan aman dibutuhkan siswa agar pendapat dan keputusannya dapat ditunjukkan selama kegiatan pembelajaran (Zafri,2012).

Rendahnya kemampuan berpikir kritis siswa dalam pembelajaran perlu mendapat perhatian serius dari semua kalangan terutama guru. Banyak faktor yang menyebabkan rendahnya kemampuan berpikir siswa dalam proses pembelajaran. Salah satunya adalah pembelajaran yang berpusat pada guru (konvensional) seperti yang sering diterapkan disekolah-sekolah selama ini, dimana peran guru lebih dominan sehinga siswa cenderung pasif. Kegiatan dalam pembelajaran konvensional biasanya diawali dengan guru menjelaskan konsep secara informatif, memberikan contoh soal dan diakhiri dengan pemberian latihan soal-soal. Akibatnya siswa lebih diarahkan pada proses menghafal dari pada memahami konsep sehingga kemampuan berpikir siswa seperti kemampuan berpikir kritis menjadi kurang berkembang menjadi kurang berkembang (Ismaimuza, 2010). 


\section{KESIMPULAN}

Berdasarkan penelitian yang telah dilakukan maka dapat disimpulkan bahwa:

Kemampuan berpikir kritis siswa pada materi Sistem Pencernaan Manusia di kelas XI IPA SMA Swasta YAPIM Biru-biru, Delitua Tahun Pembelajaran 2017/2018 berada pada kriteria cukup sampai dengan sangat baik $(79,41 \%)$ sebanyak 27 siswa. Hasil observasi rata-rata kemampuanberpikirkritis paling tinggi ditemukan pada indikator 4 (Mengobservasi dan mempertimbangkan hasil observasi) yaitu sebesar $81 \%$, sedangkan rata-rata kemampuan berpikir kritis paling rendah ditemukan pada indikator 2 (Bertanya dan menjawab pertanyaan) yaitu sebesar $59,65 \%$.

\section{UCAPAN TERIMA KASIH}

Penulis mengucapkan terima kasih kepada staf dan para dosen FMIPA Pendidikan Biologi serta Guru SMA Swasta YAPIM Biru-biru, Delitua khususnya Ibu Elista Sianturi, S.Pd, selaku guru biologi saya yang telah banyak membantu dan memberikan arahan dalam penyelesaian penelitian saya ini. Teman-teman khususnya buat sahabat pendidikan biologi EKS. A 2013 yang banyak memberikan kesan yang luar biasa kepada penulis.

\section{DAFTAR PUSTAKA}

Ardhi. W., (2012), Pembelajaran Melalui Guided Inquiry Model Menggunakan Teknik Mind Map dan Teknik Modifled Roundhouse Diagram Ditinjau dari Keterampilan Berpikir Kritis dan Keterampilan Proses Sains Mahasiswa. Jurnal Pendidikan, hlm.1197.

Arnyana, I. B. P. (2006), Pengaruh Penerapan Strategi Pembelajaran Inovatif Pada Pelajaran Biologi Terhadap Kemampuan Berpikir Kreatif Siswa SMA. Jurnal Pendidikan dan Pengajaran IKIP Negeri Singaraja, Vol.3,hlm. 496-515.

Arnyana, (2005), Pengaruh Pembelajaran Pendekatan Saintifik Terhadap Hasil Belajar Biologi dan Keterampilan Proses Sains Siswa MA. Mu allimat NW Pancor Selong Lombok Timur. Jurnal Pendidikan IPA Indonesia, Vol.4 (1),hlm.191-252.

Djamarah, B.S., (2011), Psikologi Belajar. Rineka Cipta. Jakarta.
Erdi, S., (2014), Penerapan Pembelajaran Berbasis Masalah (PBL) untuk Meningkatkan Kemampuan Berpikir Kritis Siswa pada Konsep Sistem Pernapasan Manusia di SMA negeri 11 Banda Aceh. Jurnal EduBio Tropika Vol. 2(1),hlm.121-186.

Harjanto, (2011), Perencanaan Pengajaran, Rineka Cipta. Jakarta.

Ismaimuza, (2010), Kemampuan Berpikir Kritis dan Kreatif Matematis Siswa SMP Melalui Pembelajaran Berbasis Masalah dengan Strategi Konflik Kognitif. Tesis, Universitas Pendidikan Indonesia.

Nurhidayati, (2011), Analisis Kemampuan Berpikir Kritis Siswa dalam Memecahkan Soal pada Materi Virus di SMA Negeri 3 Kota Jambi. Jurnal Pendidikan, hlm 1-14

Sudjana, N, (2008), Penilaian Hasil Proses Belajar Mengajar, PT Remaja Rosdakarya, Bandung.

Sukardi, (2013), Metodologi Penelitian Pendidikan Kompetrnsi dan Praktiknya. PT Bumi Aksara, Jakarta.

Yunita, (2016), Analisis Kemampuan Berpikir Kritis dan Hasil Belajar Siswa pada Pembelajaran Biologi di Kelas X Madrasah Aliyah Negeri 1 Medan Tahun Pembelajaran 2015/2016. Skripsi. Medan: FMIPA Universitas Negeri Medan.

Zafri, (2012), Berpikir Kritis Pembelajaran Sejarah, Jurnal Diakronika FIS UNP. 